\title{
Deteksi Kematangan Buah Jambu Kristal Berdasarkan Fitur Warna Menggunakan Metode Transformasi Ruang Warna Hsv (Hue Saturation Value) Dan K-Nearest Neighbor
}

\section{Maturity Detection of Crystal Guava Fruit Based on Color Features Using Hsv (Hue Saturation Value) and K-Nearest Neighbor Color Space Transformation Methods}

\author{
Adhi Wibowo(1), Diwahana Mutiara Candrasari Hermanto ${ }^{1)}$, Kusuma Indah Lestari $^{1)}$ \& Hadion \\ Wijoyo $^{2)}$ \\ 1)STIKOM Yos Sudarso, Indonesia \\ 2) STMIK Dharmapala, Indonesia \\ *Coresponding Email: adhi.wibowo@stikomvos.ac.id
}

\begin{abstract}
Abstrak
Jambu memiliki sifat yang mudah rusak, penangan yang tidak tepat pada buah jambu dapat mengakibatkan penuruan mutu dan kualitas. Pada umumnya, untuk mengukur kematangan masih dikerjakan secara manual, kelemahan dari metode tersebut adalah tingkat akurasi yang tidak konsisten dan cenderung mengalami kesalahan. Pemanfaatan citra sangat penting untuk mengetahui kematangan buah jambu dengan memanfaatkan citra digital. Dengan adanya citra digital maka untuk menentukan kematangan buah jambu berdasarkan warnanya bisa dilakukan secara computing (berbasis teknologi), yaitu dengan menerapkan pengolahan citra menggunakan metode transformasi ruang warna HSV (Hue, Saturation, Value). Model warna HSV (Hue, Saturation, Value) mengelompokkan komponen intensitas dari informasi warna yang dibawa (hue dan saturation) dalam warna citra. Hasil dari deteksi kematangan dapat dilihat pada masing-masing pengujian dengan nilai presentase 91,67\% untuk kategori buah jambu matang, $90 \%$ untuk kategori buah jambu mentah. Nilai presentase untuk pengujian keseluruhan data mempunyai presentase nilai yang baik dimana berpengaruh dalam mendeteksi kematangan jambu kristal yaitu sebesar 95\%. Maka dapat disimpulkan, bahwa pendeteksian kematangan buah jambu kristal dapat dilakukan dengan menerapkan metode transformasi ruang warna HSV.
\end{abstract}

Kata Kunci : Transformasi Ruang Warna HSV; Pengolahan Citra.

\section{Abstract}

Guava has properties that are easily damaged, improper handling of guava fruit can result in a decrease in quality and quality. In general, to measure maturity is still done manually, the weakness of this method is the level of accuracy that is not consistent and tends to experience errors. Utilization of images is very important to determine the maturity of guava fruit by utilizing digital images. With the existence of digital images, to determine the maturity of guava fruit based on its color, it can be done computing (technology-based), namely by applying image processing using the HSV (Hue, Saturation, Value) color space transformation method. The HSV (Hue, Saturation, Value) color model groups the intensity components of the carried color information (hue and saturation) in image colors. The results of the ripeness detection can be seen in each test with a percentage value of $91.67 \%$ for the ripe guava category, 90\% for the raw guava fruit category. The percentage value for testing the overall data has a good percentage value which is influential in detecting the maturity of crystal guava, which is $95 \%$. So it can be concluded that the detection of ripeness of crystal guava fruit can be done by applying the HSV color space transformation method.

Keywords: HSV Color Space Transformation; Image Processing. 


\section{PENDAHULUAN}

Perkembangan dunia Teknologi Informasi saat ini berkembang dengan sangat pesat, yang diikuti dengan berbagai ragam inovasi yang dapat di ciptakan. Salah satu inovasi Teknologi Informasi yang memiliki tingkat antusiasme yang sangat tinggi untuk diteliti dan dikembangkan yaitu pengolahan citra digital. Perkembangan internet dalam dunia Teknologi Informasi memiliki andil besar dalam akumulasi pengolahan citra digital dalam bidang pertanian. Teknologi yang canggih memberikan kemudahan bagi pekerjaan manusia, sehingga yang dahulu masih dikerjakan manusia, kini sudah bisa digantikan oleh tenaga mesin (komputer). Saat ini aplikasi komputer sudah banyak digunakan dalam mempermudah pekerjaan manusia, seperti halnya pada bidang kedokteran, kemiliteran, industri, perdagangan, pertanian dan lain sebagainya, sehingga komputer menjadi sebuah alat yang handal dalam membantu kebutuhan manusia saat ini.

Citra merupakan representasi, kemiripan atau imitasi dari suatu objek. Perkembangan teknologi kamera semakin berkembang, dengan didukungnya oleh perangkat lunak dan perangkat keras pada kamera, seperti kamera smartphone, ct scan, rontgen, sensor dan lain-lain. Dengan adanya bantuan kamera citra dapat dimanfaatkan untuk diolah dengan adanya kelebihan-kelebihan yang dimiliki oleh citra digital tersebut maka gambar mudah untuk didapatkan maupun diperbanyak.

Jambu kristal adalah tanaman buah yang kaya akan sumber vitamin dan mineral untuk tubuh yang banyak digemari masyarakat karena rasanya yang segar dan mengandung vitamin $\mathrm{C}$ yang bagus untuk tubuh. Jambu kristal memiliki keunggulan dalam cita rasa, mudah dibudidayakan, frekuensi panen yang tinggi, peluang wirausaha dengan permintaan tinggi, dan terus meningkat sebagai komoditas potensial untuk dikembangkan.

Salah satu permasalahan pascapanen pada buah jambu kristal yang diproduksi secara skala besar atau industri adalah dalam hal penyortiran buah. Selama ini buah jambu kristal diidentifikasi tingkat kematangannya berdasarkan analisis warna kulit buah secara visual mata manusia. Proses identifikasi seperti ini memiliki beberapa kelemahan di antaranya yaitu membutuhkan tenaga lebih banyak untuk memilah, dan tingkat persepsi kematangan buah yang dihasilkan bisa berbeda karena manusia dapat mengalami kelelahan, tidak selalu konsisten, dan penilaian manusia juga bersifat subjektif. 
Dengan adanya citra digital maka untuk menentukan kematangan buah jambu kristal berdasarkan warnanya bisa dilakukan secara computing (berbasis teknologi). Salah satu indikator untuk menentukan kematangan buah jambu kristal yang dipakai adalah warna buah yang mentah dan matang sehingga dapat dilakukan dengan memanfaatkan pengolahan citra menggunakan metode Transformasi ruang warna HSV (hue, saturation, value).

Model warna HSV (hue, saturation, value) merupakan salah satu sistem warna yang digunakan manusia dalam memilih warna objek. Nilai HSV diperoleh dari konversi nilai RGB citra. Sistem HSV dipandang lebih dekat dari pada sistem RGB dalam mendeskripsikan sensasi warna oleh mata manusia. Dengan menggunakan HSV, objek dengan warna tertentu dapat dideteksi dan mengurangi intensitas cahaya dari luar (Febri \& Fitri, 2018). [1]

\section{METODE PENELITIAN}

Beberapa penelitian sebelumnya yang pernah dilakukan antara lain, yaitu: dimana dalam penelitian Reni Rahmadewi, yang telah meneliti tentang pendeteksian kematangan buah jeruk dengan fitur citra kulit buah menggunakan transformasi ruang warna HSV, dari pengujian 30 sampel menghasilkan tiga klasifikasi nilai rentang Hue, yaitu warna hijau dengan nilai Hue (30.224 - 68.68) untuk jeruk mentah, warna kunig kemerahan dengan nilai Hue (11.914 - 29.688) untuk jeruk matang dan warna merah tua gelap dengan nilai Hue (0.627 - 8.991) untuk jeruk telalu matang (Reni, Gina \& Hirlan, 2019) [2]. Penelitian selanjutnya oleh Husnul Khotimah yang terkait dengan proses pengolahan citra adalah klasifikasi tingkat kematangan buah mangga berdasarkan citra HSV dengan KNN, dimana akurasi yang didapatkan dari pengujian data testing memiliki rata-rata akurasi 55\% dengan jarak antara $K=10$ (Husnul \& Nur, 2019) [3]. Selanjutnya dalam penelitian Nina Sularida, yang terkait identifikasi tingkat kematangan buah pisang menggunakan metode ektraksi ciri statistik pada warna kulit buah, yang menghasilkan nilai maksimum, minimum dan mean dari piksel untuk ruang warna RGB dan HSV diperoleh rata-rata tingkat akurasi untuk sebesar 90\% (Nina, Jayanti \& Ika , 2018) [4].

\section{Citra}

Citra merupakan istilah lain untuk gambar sebagai salah satu komponen multimedia yang memegang peran sangat penting sebagai bentuk informasi visual. Citra mempunyai 
karakteristik yang tidak dimiliki oleh data teks, yaitu citra kaya dengan informasi [9]. Dalam penelitian [10], citra merupakan gambar pada bidang dwimatra atau fungsi menerus dari intensitas cahaya pada bidang dwimatra. Citra merupakan bentuk informasi visual sehingga banyak informasi yang dapat digali dari sebuah citra digital.

\section{Citra Biner}

Citra biner merupakan citra yang hanya memiliki dua buah pixel yaitu hitam bernilai 0 dan putih bernilai 1. Maka setiap pixel pada citra biner cukup direpresentasikan dengan 1 bit.

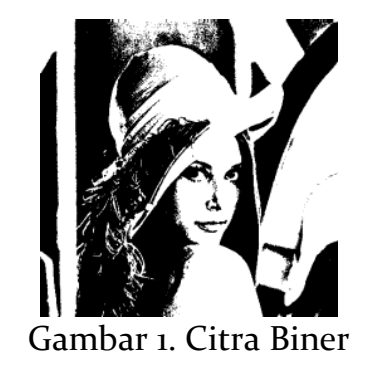

\section{Representasi Biner}
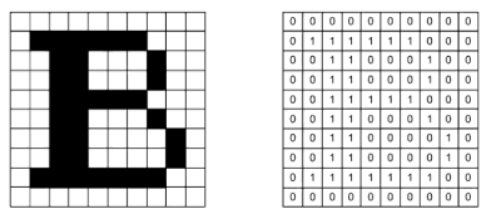

Gambar 2. Represntasi Citra Biner

\section{Citra RGB}

Citra RGB (citra berwarna) merupakan citra yang masing-masing piksel mempunyai 3 (tiga) komponen warna yang spesifik, yaitu komponen merah (red), hijau (green) dan biru (blue) [4]. Ruang warna RGB untuk citra turecolor 24 bit diilustrasikan oleh gambar berikut : 


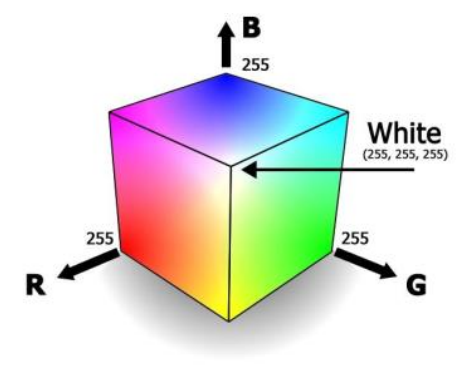

Gambar 3. Ruang Warna RGB

Citra warna merupakan citra yang setiap pikselnya mewakili warna kombinasi dari tiga warna dasar yaitu merah, hijau, dan biru. Setiap warna dasar ini menggunakan penyimpanan 8 bit atau 1 byte, yang setiap warna mempunyai gradasi sebanyak 256 warna. Hal ini menunjukkan setiap piksel dalam citra berwarna mempunyai kombinasi warna sebanyak $2^{8} \cdot 2^{8 \cdot} 2^{8}=2^{24}=16$ juta lebih, dengan adanya true color ini mempunyai jumlah warna yang besar sehingga bisa dikatakan hampir mencakup selueuh warna di alam.

\section{Pengolahan Citra}

Pengolahan citra merupakan suatu metode atau teknik yang dapat digunakan untuk memproses citra atau gambar dengan cara memanipulasinya menjadi data citra yang diinginkan untuk mendapatkan informasi tertentu [9].

\section{Konversi RGB to HSV}

Model warna HSV merupakan model warna yang diturunkan dari model warna RGB maka untuk mendapatkan warna HSV ini, harus melakukan proses konversi nilai warna RGB ke HSV [2]. RGB merupakan singkatan dari Red, Green, Blue. Warna-warna yang dibentuk oleh model warna merupakan hasil campuran dari warna-warna primer merah, hijau, dan biru berdasarkan komposisi tertentu.

Untuk mentransformasikan dari RGB ke HSV. Diasumsikan koordinat-koordinat R, G dan B (0 atau 1) adalah berurutan merah, hijau dan biru dalam ruang warna RGB, max adalah nilai maksimum dari nilai (red, green, dan blue) dan min adalah nilai minimum dari nilai (red, green dan blue). Untuk memperoleh sudut Hue [0,360] yang tepat untuk ruang warna HSV. Perhitungn konversi RGB menjadi HSV dapat dirumuskan sebagai berikut:

1. Menghitung nilai RGB dalam bentuk normalisasi:

$$
r=\frac{R}{(R+G+B)}, g=\frac{G}{(R+G+B)}, b=\frac{B}{(R+G+B)}
$$

2. Menghitung nilai Value:

$$
V=\max (r, g, b)
$$

3. Menghitung nilai Saturasi: 


$$
\begin{aligned}
& S=\left\{\begin{array}{cl}
0 & \text { jika } V=0 \\
1-\frac{\min (r, g, b)}{V}, & \text { jika } V>0
\end{array}\right. \\
& \text { 4. Menghitung nilai Hue: } \\
& H=\left\{\begin{array}{cl}
0 & \text { jika } S=0 \\
\frac{60 *(g-b)}{S * V}, & \text { jika } V=r \\
60 *\left[2+\frac{b-r}{S * V}\right], & \text { jika } V=g \\
60 *\left[4+\frac{r-g}{S * V}\right], & \text { jika } V=b
\end{array}\right. \\
& H=H+360 \quad \text { jika } H<0 \\
& \text { R : Nilai piksel red } \\
& \text { G : Nilai piksel green } \\
& \text { B : Nilai piksel blue } \\
& \mathrm{H} \text { : Nilai piksel hue } \\
& \text { S : Nilai piksel saturation } \\
& \text { V : Nilai piksel value }
\end{aligned}
$$

\section{Transorfmasi Ruang Warna HSV}

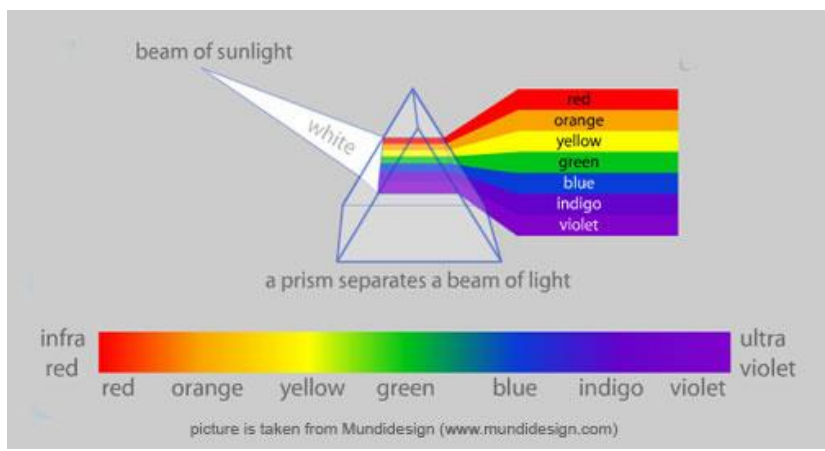

Gambar 4. Spektrum Warna HSV

Model HSV (Hue Saturation Value) merupakan warna yang terdiri dari tiga warna utama yaitu hue, saturation, dan value (atau disebut juga brigthness). Hue merupakan dengan sudut dari 0 sampai 360 derajat, biasanya 0 adalah merah, 60 derajat adalah kuning, 120 derajat adalah hijau, 180 dearat adalah cyan, 240 derajat adalah biru, dan 300 derajat adalah warna magenta. Hue menunjukkan jenis warna atau corak warna yaitu 
tempat warna tersebut ditemukan dalam spektrum warna. Saturation dari suatu warna adalah ukuran seberapa besar kemurnian dari warna tersebut. Value atau disebut juga intensity yaitu ukuran seberapa bersar kecerahan dari suatu warna atau seberapa besar cahaya datang dari suatu warna. Value dapat bernilai dari 0-100\% [12].

Flowchart

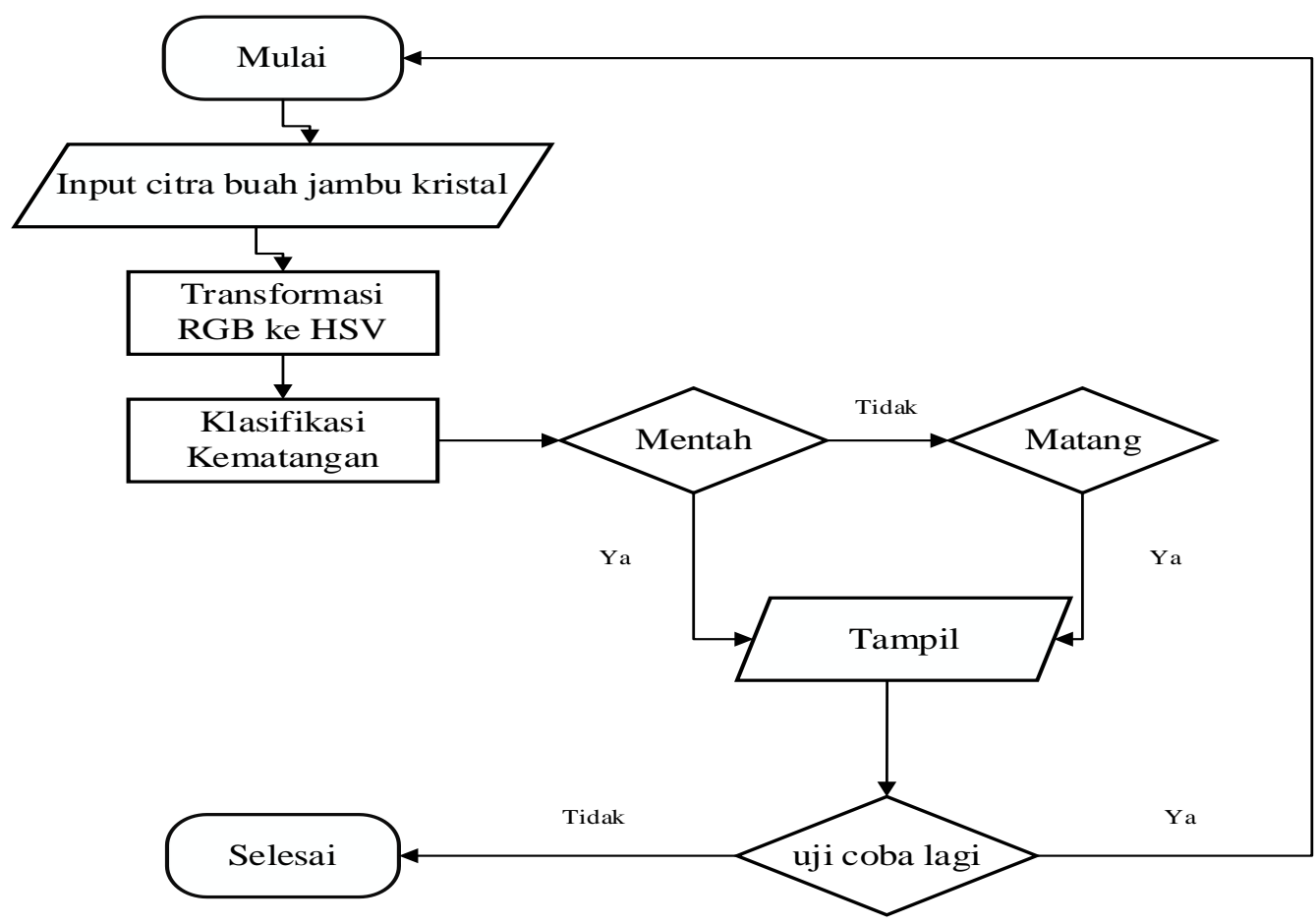

Gambar 11. Alur metode transformasi ruang warna hsv

Diagram alir transformasi ruang warna hsv ini merupakan gambaran dari langkahlangkah penerapan metode hsv. Cara kerja dari perancangan gui matlab adalah sebagai berikut ;

1. Langkah awal dimulai dari input citra kulit jambu kristal

2. Kemudian mentransformasikan ruang warna rgb ke ruang warna hsv

3. Selanjutnya klasifikasi kematangan buah jambu kristal yang sesuai dengan kelasnya masing-masing.

4. Apabila deteksi kematangan buah jambu masuk kedalam kelas mentah maka akan ditampilkan citra jambu kristal mentah, bila jambu kristal masuk kedalam kelas matang maka akan ditampilkan citra jambu kristal matang.

5. Setelah masuk kedalam kelas mentah dan matang proses selanjutnya adalah uji coba lagi hingga sesuai dengan keadaan citra buah jambu kristal.

6. Deteksi kematangan selesai. 


\section{HASIL DAN PEMBAHASAN}

Pengujian perancangan ini dilakukan dengan cara observasi secara langsung terhadap gui matlab dan didapatkan hasil pada setiap percobaan. Dengan menggunakan metode transformasi ruang warna hsv, dimana metode ini digunakan untuk pengambilan warna, transformasi warna hsv akan menyimpan data dan nantinya akan digunakan pada citra digital sebelumnya untuk mendapatkan nilai citra yang lebih optimal.

Dalam penelitian ini tahap pengujian sistem dilakukan dengan pemrosesan terhadap 160 citra buah jambu kristal yang berekstensi *jpg. Dari 160 jenis citra tersebut akan diproses menggunakan metode transformasi ruang warna hsv. Diambil sampel sebanyak 100 buah pada masing-masing kondisi jambu kristal mentah dan matang. Citra jambu kristal dengan format jpg akan dihitung RGB-nya dan dilakukan transformasi ke ruang warna hsv. Setelah didapatkan hasil dari perhitungan masing-masing citra buah jambu kristal, kemudian dihitung rata-rata $\mathrm{H}$, rata-rata $\mathrm{S}$, dan rata-rata $\mathrm{V}$. Kemudian dilakukan pengecekan klasifikasi citra jambu kristal menurut fase kematangan jambu kristal. Hal ini dilakukan agar mendapatkan nilai range maksimal dan saat pengambilan keputusan kematangan jambu kristal sehigga akurat.

Pada tahap pengujian berdasarkan hasil dari deteksi warna kulit buah jambu kristal dalam ruang warna krominan memiliki nilai-nilai yang berguna untuk mempermudah klasifikkasi warna kulit jambu kristal dalam fase kematangan. Jumlah sampel yang digunakan untuk proses pengujian adalah 160 citra jambu yang berekstensi jpg. Dari 160 jenis citra buah jambu kristal akan diproses dan dicari nilai RGB kemudian ditransformasikan ke ruang warna HSV.

Dimana telah diambil sampel sebanyak 60 buah jambu kristal matang, 40 buah jambu kristal mentah. Setelah dilakukan pemrosesan terhadap citra tersebut maka selanjutnya dilakukan pengecekan klasifikasi warna kulit buah jambu kristal yang menajdi acuan dalam klasifikasi warna buah jambu kristal. Jika nilai perhitungan yang dilakukan berada pada range nilai warna kulit buah jambu kristal, maka warna buah jambu kristal dapat diklasifikasikan sesuai dengan range nilai yang telah ditentukan klasifikasi kematangannya. Tabel hasil klasifikasi warna kulit buah jambu kristal dengan deteksi warna dalam ruang krominan dapat dilihat sebagai berikut :

Tabel 8. kematangan jambu kristal

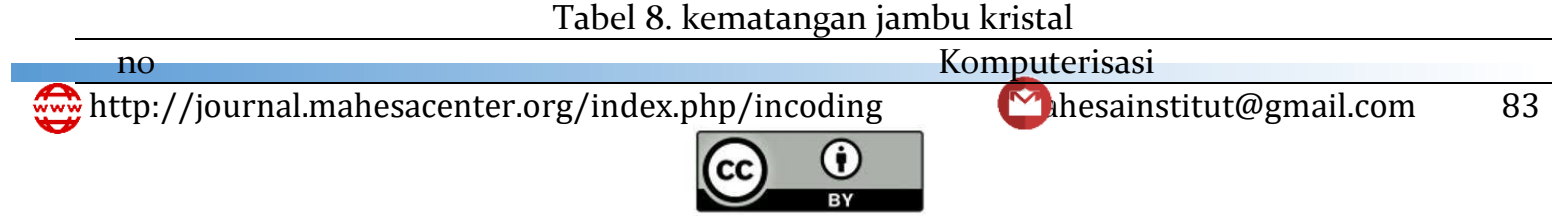

This work is licensed under a Creative Commons Attribution 4. 
Adhi Wibowo, Diwahana Mutiara Candrasari Hermanto, Kusuma Indah Lestari \& Hadion Wijoyo, Deteksi

\begin{tabular}{|c|c|c|c|c|c|c|c|c|}
\hline & \multirow{2}{*}{$\begin{array}{c}\text { Kode } \\
\text { Sampel }\end{array}$} & \multirow{2}{*}{$\begin{array}{c}\text { Citra } \\
\text { Sampel }\end{array}$} & \multicolumn{3}{|c|}{ Hasil perhitungan } & \multicolumn{2}{|c|}{ Fase kematangan } & \multirow[t]{2}{*}{ Ket } \\
\hline & & & $\mathrm{H}$ & $\mathrm{S}$ & $\mathrm{V}$ & Petani & Komputer & \\
\hline 1 & $\mathrm{~K}_{1}$ & & 0,1859 & 0,4582 & 0,5535 & $\checkmark$ & $\checkmark$ & $\checkmark$ \\
\hline 2 & $\mathrm{~K}_{2}$ & & 0,1734 & $\begin{array}{c}0,404 \\
4\end{array}$ & 0,5862 & $\checkmark$ & $\checkmark$ & $\checkmark$ \\
\hline 3 & $\mathrm{~K}_{3}$ & & 0,2992 & 0,2450 & 0,5807 & $\checkmark$ & $\checkmark$ & $\checkmark$ \\
\hline 4 & $\mathrm{~K}_{4}$ & & 0,1947 & 0,4329 & 0,5461 & $\checkmark$ & $\checkmark$ & $\checkmark$ \\
\hline 5 & $\mathrm{~K}_{5}$ & & 0,1831 & 0,4143 & 0,5590 & $\checkmark$ & $\checkmark$ & $\checkmark$ \\
\hline 6 & K6 & & 0,1779 & $\begin{array}{c}0,460 \\
2\end{array}$ & 0,5861 & $\checkmark$ & $\checkmark$ & $\checkmark$ \\
\hline 7 & $\mathrm{~K}_{7}$ & & 0,2544 & 0,3802 & 0,5892 & $\checkmark$ & $\checkmark$ & $\checkmark$ \\
\hline 8 & K8 & & 0,1889 & 0,5547 & $\begin{array}{c}0,500 \\
0\end{array}$ & $\checkmark$ & $\checkmark$ & $\checkmark$ \\
\hline 9 & K9 & & 0,1847 & 0,4777 & 0,5740 & $\checkmark$ & $\checkmark$ & $\checkmark$ \\
\hline 10 & K10 & & 0,1894 & 0,4772 & $\begin{array}{c}0,486 \\
4\end{array}$ & $\checkmark$ & $\checkmark$ & $\checkmark$ \\
\hline
\end{tabular}

\begin{tabular}{llllllll}
\hline$\ldots$ & & & & & & & \\
\hline 150 & K150 & 0,1956 & 0,4672 & 0,4835 & $\checkmark$ & $\checkmark$ & $\checkmark$ \\
\hline & Rata-rata & & 0,2109 & 0,3782 & 0,5356 & & \\
& & & & & & & \\
\hline
\end{tabular}

\begin{tabular}{|c|c|c|c|c|c|c|c|c|}
\hline \multirow[t]{3}{*}{ no } & \multirow{3}{*}{$\begin{array}{l}\text { Kode } \\
\text { Sampel }\end{array}$} & \multirow{3}{*}{$\begin{array}{l}\text { Citra } \\
\text { Sampel }\end{array}$} & \multicolumn{6}{|c|}{ Komputerisasi } \\
\hline & & & \multicolumn{3}{|c|}{ Hasil perhitungan } & \multicolumn{2}{|c|}{ Fase kematangan } & \multirow[t]{2}{*}{ Ket } \\
\hline & & & $\mathrm{H}$ & $\mathrm{S}$ & $\mathrm{V}$ & Petani & Komputer & \\
\hline 1 & K1 & & $\begin{array}{l}0,200 \\
6\end{array}$ & 0,6710 & 0,4297 & $\checkmark$ & $\checkmark$ & $\checkmark$ \\
\hline 2 & $\mathrm{~K} 2$ & & 0,2106 & 0,6257 & 0,4639 & $\checkmark$ & $\checkmark$ & $\checkmark$ \\
\hline 3 & $\mathrm{~K}_{3}$ & & 0,1946 & 0,6472 & $\begin{array}{l}0,444 \\
4\end{array}$ & $\checkmark$ & $\checkmark$ & $\checkmark$ \\
\hline 4 & $\mathrm{~K}_{4}$ & & 0,2041 & $\begin{array}{l}0,698 \\
4\end{array}$ & 0,3545 & $\checkmark$ & $\checkmark$ & $\checkmark$ \\
\hline 5 & $\mathrm{~K}_{5}$ & & 0,2100 & 0,6934 & $0,355^{8}$ & $\checkmark$ & $\sqrt{ }$ & $\checkmark$ \\
\hline 6 & K6 & & 0,1829 & 0,6850 & $\begin{array}{l}0,470 \\
9\end{array}$ & $\checkmark$ & $\checkmark$ & $\sqrt{ }$ \\
\hline
\end{tabular}




\begin{tabular}{|c|c|c|c|c|c|c|c|}
\hline 7 & $\mathrm{~K}_{7}$ & 0,1849 & 0,7023 & $\begin{array}{l}0,464 \\
0\end{array}$ & $\checkmark$ & $\checkmark$ & $\checkmark$ \\
\hline 8 & K8 & 0,1870 & 0,7044 & 0,4562 & $\checkmark$ & $\checkmark$ & $\checkmark$ \\
\hline 9 & K9 & 0,1844 & $\begin{array}{l}0,706 \\
9\end{array}$ & 0,4370 & $\checkmark$ & $\checkmark$ & $\checkmark$ \\
\hline 10 & K10 & 0,1856 & $\begin{array}{l}0,667 \\
4\end{array}$ & 0,4430 & $\checkmark$ & $\checkmark$ & $\checkmark$ \\
\hline \multicolumn{8}{|l|}{$\ldots$} \\
\hline 110 & $\mathrm{~K}_{150}$ & 0,1887 & $\begin{array}{l}0,640 \\
2\end{array}$ & 0,3276 & $\checkmark$ & $\checkmark$ & $\checkmark$ \\
\hline Rat & & 0,1894 & 0,6720 & 0,3487 & & & \\
\hline
\end{tabular}

Berdasarkan tabel di atas diketahui bahwa buah jambu kristal matang dengan nilai $H=0,2109, S=0,3782, V=0,5356$, buah jambu kristal mentah $H=0,1894, S=0,6720, V=$ 0,3487. Pengujian gui matlab telah dilakukan dengan melakukan pemrosesan terhadap 160 citra buah jambu kristal yang berekstensi jpg. Dari 160 jenis citra tersebut telah diproses dengan menggunakan metode transformasi ruang warna HSV. Dimana pengujian sebanyak 100 buah jambu kristal matang, dan 60 buah jambu kristal mentah.

Dari hasil pengujian tersebut didapatkan tingkat keberhasilan untuk pengujian buah jambu kristal mencapai 91,67\% dari 55 data terbaca benar dan 5 data terbaca salah dari 60 data sampel citra buah jambu kristal matang, sedangkan untuk buah jambu kristal mentah mencapai $90 \%$ dari 36 data terbaca benar dan 4 data terbaca salah dari 40 data sampel citra buah jambu kristal mentah.

Untuk keseluruhan hasil pengujian dari 160 data sampel citra buah jambu kristal mencapai presentase yang tinggi yaitu 152 data terbaca benar dan 8 terbaca salah dari 160 data sampel citra buah jambu kristal. Berikut adalah data hasil pengujian yang telah dilakukan. 


$$
\begin{gathered}
\text { Akurasi }=\frac{152}{160} \times 100 \% \\
\text { Akurasi }=95 \%
\end{gathered}
$$

Dari hasil pengujian tersebut didapatkan tingkat keberhasilan untuk pengujian keseluruhan 160 sampel data citra buah jambu kristal, yang berhasil 152 data dan yang gagal 8 data, sehingga diperoleh akurasi sebesar 95\%.

Diagram akurasi diambil dari hasil pengujian dari keseluruhan data dimana pengujian buah jambu kristal matang mencapai 91,67\% dari 55 data terbaca benar dan 5 data terbaca salah dari jumlah total 60 data dikarenakan rendahnya nilai $H$ (hue) dan tingginya nilai S (saturation) sehingga menyebabkan tidak terbacanya hasil klasifikasi kematangan buah jambu kristal, untuk buah jambu kristal mentah mencapai 90\% dari 36 data terbaca benar dan 4 data terbaca salah dari 40 data dikarenakan tedapat nilai $S$ (saturation) yang rendah dan nilai S (saturation) yang tinggi sehingga menyebabkan tidak terbacanya hasil klasifikasi kematangan buah jambu kristal. Diagram akurasi untuk keseluruhan pengujian dapat dilihat pada gambar dibawah:

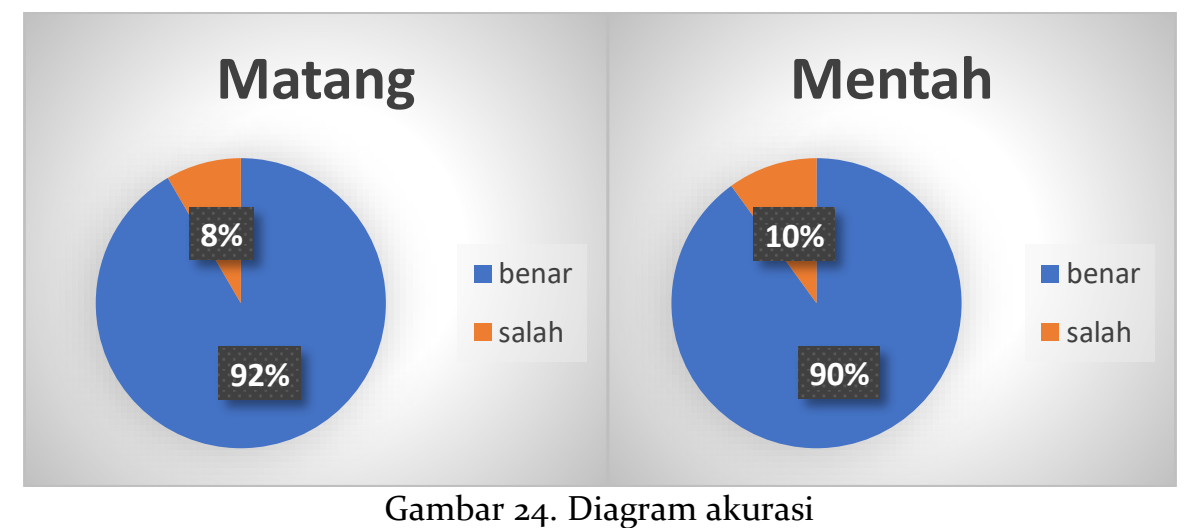

\section{SIMPULAN}

Nilai piksel sangat berpengaruh dalam menguaraikan tiga jenis citra berwarna RGB, yang nantinya akan ditransformasikan ke ruang warna HSV (Hue, Saturation, Value). Kelemahan pencahayaan yang tinggi dapat berpengaruh pada saat pengujian yaitu dari penyerapan cahaya pada objek yang berlebihan akan menghasilkan warna dari rata-rata RGB menjadi berkurang. Dilihat dari transformasi ruang warna rgb yang tersegmentasi warna hsv ini cukup baik dalam membandingkan kematangan jambu kristal satu dengan kematangan jambu kristal lain dalam mengambil ciri warnanya, dapat dilihat dari pengujian nilai piksel red, green, blue yang ditransformasikan ke nilai HSV untuk deteksi wwit http://journal.mahesacenter.org/index.php/incoding 
kematangan buah jambu kristal mempunyai hasil presentase sebesar 91,67\% dari 55 data terbaca benar dan 5 data terbaca salah dari 60 data sampel citra buah jambu kristal matang, sedangkan untuk buah jambu kristal mentah mencapai 90\% dari 36 data terbaca benar dan 4 data terbaca salah dari 40 data sampel citra buah jambu kristal mentah. Dapat disimpulkan dari hasil presentase yang diperoleh yaitu sebesar 95\%, perancangan gui ini dapat digunakan untuk mendeteksi kematangan buah jambu kristal berdasarkan fitur warna.

\section{DAFTAR PUSTAKA}

[1] Febri Liantoni, Fitri Nur Annisa, "FUZZY K-NEAREST NEIGHBOR PADA KLASIFIKASI KEMATANGAN CABAI BERDASARKAN FITUR HSV CITRA," JIPI (Jurnal Ilmiah Penelitian dan Pembelajaran Informatika), vol. 03, no. 02, pp. 101 - 108, Desember 2018.

[2] Reni Rahmadew, Gina Lova Sar, Hirlan Firmansyah, "Pendeteksian Kematangan Buah Jeruk Dengan Fitur Citra Kulit Buah Menggunakan Transformasi Ruang Warna HSV," Seminar FORTEI 2019, pp. 166-171, 2019.

[3] Husnul Khotimah, Nur Nafi'iyah, Masruroh, "Klasifikasi Kematangan Buah Mangga Berdasarkan Citra HSV dengan KNN," ELTI, vol. 1, no. 2, pp. 1-4, Desember 2019.

[4] Nina Sularida, Jayanti Yusnah, Ika Purwanti, "Identifikasi Tingkat Kematangan Buah Pisang Menggunakan Metode Ektraksi Ciri StatistikPada Warna Kulit Buah," ULTIMATICS, vol. X, no. 2, pp. 98-102, 2018.

[5] Antonio Ciputra, De Rosal Ignatius Moses Setiadi, Eko Hari Rachmawanto, Ajib Susanto , "KLASIFIKASI TINGKAT KEMATANGAN BUAH APEL MANALAGI DENGAN ALGORITMA NAIVE BAYES DAN EKSTRAKSI FITUR CITRA DIGITAL," Jurnal SIMETRIS, vol. 9, no. 1, ISSN: 2252-4983, pp. 456472, April 2018.

[6] R. Febrizal, "Pengembangan Metode Pengukuran Tingkat Kematangan Buah Jambu Kristal Menggunakan Pengolahan Citra," Fakultas Teknologi Pertanian Institut Pertanian Bogor, pp. 18-23, 2017.

[7] S. N. Indonesia, "Jambu Biji," Badan Standarisasi Nasional, pp. 1-16, 2009.

[8] RETNO NUGROHO WHIDHIASIH, SUGI GURITMAN, PRAPTO TRI SUPRIO, "Klasifikasi Kematangan Buah Manggis Ekspor dan Lokal Berdasarkan Warna dan Tekstur Menggunakan Fuzzy Neural Network," Ilmu Komputer Agri-Informatika, vol. 1, no. ISSN: 2089-6026 2, pp. 71-77, 2012.

[9] Rendy Pratama, Achmad Fuad Assagaf, Firman Tempola, "DETEKSI KEMATANGAN BUAH TOMAT BERDASARKAN FITUR WARNA MENGGUNAKAN METODE TRANSFORMASI RUANG WARNA HIS," Jurnal Informatika dan Ilmu Komputer (JIKO), vol. 2, no. 2, pp. 81-86, Oktober 2019.

[10] Pawit Rianto, Agus Harjoko, "Penentuan Kematangan Buah Salak Pondoh Di Pohon Berbasis Pengolahan Citra Digital," IJCCS, vol. 11, no. ISSN: 1978-1520, 2, pp. 143-154, July 2017,.

[11] Muhamad Nasir, Nanik Suciati, Arya Yudhi Wijaya, "Kombinasi Fitur Tekstur Local Binary Pattern yang Invariant Terhadap Rotasi dengan Fitur Warna Berbasis Ruang Warna HSV untuk Temu Kembali Citra Kain Tradisional," Jurnal Inspiraton, vol. 7, no. 1, pp. 42-51, Juni 2017.

[12] Febri Liantoni, Hendro Nugroho, "Perbaikan Kontras Citra Dengan Ekualisasi Histogram Dan Gaussian Pada Klasifikasi Semangka," JURNAL INFORMATIKA UPGRIS, vol. 5, no. 1, pp. 35-39, 2019. 
[13] Indarto, Murinto, "Deteksi Kematangan Buah Pisang Berdasarkan Fitur Warna Citra Kulit Pisang Menggunakan Metode Transformasi Ruang Warna HIS (Banana Fruit Detection Based on Banana Skin Image Features Using HSI Color Space Transformation Method)," JUITA, vol. 5, no. 1, ISSN: 2086-9398, pp. 15-21, mei 2017.

[14] N. W. R. Situmorang, "Penerapan Metode K-Nearest Neighbor Dalam Identifikasi Kesegaran Ikan," Jurusan Teknologi Informasi,Universitas Sumatera Utara, Medan, pp. 16-76, 2019.

[15] R. P. Rakhmawati, "Sistem Deteksi Jenis Bunga Menggunakan Nilai HSV Dari Citra Mahkota Bunga," Skripsi, Fakultas Teknologi Informasi, Universitas STKIUBANK (UNISBANK), Semarang, pp. 2144, 2013.

[16] Karunia Ayuningsih, Yuita Arum Sari, Putra Pandu Adikara, "Klasifikasi Citra Makanan Menggunakan HSV Color Moment dan Local Binary Pattern dengan Naïve Bayes Classifier," Jurnal Pengembangan Teknologi Informasi dan Ilmu Komputer, vol. 03, no. 4, pp. 3166-3173, April 2019. 